\title{
Optimization of important production factors of a non-alcoholic beverage from roselle calyx, sorghum stem sheath and local spices
}

\author{
${ }^{1}$ Adekanye, B.R., ${ }^{2}$ Arinkoola, O.A., ${ }^{1}$ Abioye, A.O. and ${ }^{1 *}$ Ade-Omowaye, B.I.O \\ ${ }^{1}$ Department of Food Science and Engineering, Ladoke Akintola University of Technology, P.M.B. 4000, \\ Ogbomoso, Oyo State, Nigeria \\ ${ }^{2}$ Department of Chemical Engineering, Ladoke Akintola University of Technology, P.M.B. 4000, Ogbomoso, \\ Oyo State, Nigeria
}

\begin{abstract}
Article history:
Received: 7 September 2017

Received in revised form: 27

September 2017

Accepted: 7 October 2017

Available Online: 21 October 2017
\end{abstract}

\section{Keywords:}

Local spices,

Important processing

variables,

Response,

Roselle calyx,

Sorghum stem sheath

DOI:

https://doi.org/10.26656/fr.2017.2(1).218

\begin{abstract}
RSM was used to optimize the important processing variables for a non-alcoholic beverage (NAB) from roselle calyx, sorghum stem sheath and two local spices. A CCRD consisting of six variables reduced to five for mathematical convenience [Roselle Calyx/ Sorghum Stem Sheath, (RC/SSS, 0-75/25-100 g), ginger $(0-1.50 \mathrm{~g} / 100 \mathrm{ml})$, Alligator Pepper (AP, $0-1.50 \mathrm{~g} / 100 \mathrm{ml})$, Extraction Temperature $\left(\mathrm{ET}, 80-100^{\circ} \mathrm{C}\right)$ and Time of Extraction (TOE, 20-40 min)] with five coded levels $(-2,-1,0,+1,+2)$ were studied with two replications, making 54 experiments. Mathematical models were developed for the responses [Vitamin C (VC), Total Carotenoids (TC), 1, 1 -Diphenyl-2-picrylhydrazyl (DPPH), Total Phenols (TP), pH, Total Titratable Acidity (TTA)] for making a prediction during NAB production. Storage stability indices [pH, VC, TTA, Total Viable (TVC) and coliform counts] of the beverage were monitored for 28 days. The optimum processing variables were RC/SSS, $66.67 \mathrm{~g} / 33.33 \mathrm{~g}$; ginger, $0.375 \mathrm{~g} / 100 \mathrm{ml}$; AP, $0.375 \mathrm{~g} / 100 \mathrm{ml}$; ET, $85^{\circ} \mathrm{C}$; and TOE, $35 \mathrm{~min}$, yielding actual values of $15.33,1757.2,0.306(\mathrm{mg} / 100 \mathrm{ml})$, $89.21 \%$ for VC, TC, TP and DPPH respectively. The developed mathematical models for the measured responses could be successfully used for their prediction during nonalcoholic beverage production with a correlation coefficient $\left(\mathrm{R}^{2}\right)$ ranging from 0.84-0.99. Reduction in $\mathrm{pH}(4.98-2.66)$ and VC (15.33 -12.69 mg/100 ml) were observed while TTA increased (1.70-5.02\%) during storage. There was no coliform growth throughout the storage period, however, after 7 days, TVC was $7 \times 10^{2} \mathrm{CFU} / \mathrm{ml}$.
\end{abstract}

\section{Introduction}

Beverages are consumed to provide refreshment, hydration, increase well-being and to prevent the occurrence of nutrition-related disorders (Tenge and Geiger, 2001). Non-alcoholic beverages (NABs) are recognized because they contribute to household nutrition and they perform a special role in hydrating the body (EFSA, 2011). NABs are also rich in essential amino acids, vitamins and minerals, therefore they are used in nutrition-enhancing programs (Dharmasena, 2010). In the Western markets, beverage consumers prefer drinks that have healthful benefits to the commonly consumed soft drinks. The human health depends on the quality of the consumed beverages (WCRF, 2011). Consumers are increasingly aware of the impact of diet on their health and well-being. The increase in health awareness has resulted in a shift from consumption of soft drinks which have been linked to certain diseases to health-promoting beverages.

The imbalance between pro-oxidants and antioxidants in an organism that causes oxidative stress is considered to play a very important role in the pathogenesis of several chronic diseases, such as diabetes, cancer, and cardiovascular diseases, including arterial sclerosis, aging and neurodegenerative diseases (Bagchi et al., 2000). However, the natural defense in the human body may not be enough for severe oxidative stress (Tedesco et al., 2000). Hence, certain amounts of external antioxidants are constantly required to maintain an adequate level of antioxidants in order to balance the Reactive Oxygen Species-scavengers (ROS) (Tedesco et al., 2000). These antioxidants can be obtained from plant 
food materials such as roselle calyces, sorghum stem sheath, and spices.

Roselle calyx has been used by people in Africa either directly or indirectly in the treatment of several diseases such as abscesses, bilious conditions, cancer, cough, debility, dyspepsia, fever, hangover, heart ailments, hypertension, and neurosis (Tom et al., 2013). The calyx extracts are used for the treatment of several complaints, including high blood pressure and liver diseases. The pharmacological actions of the calyx extracts include strong in vitro and in vivo antioxidant activity (Ali et al., 2005). Sorghum bicolor leaf sheaths (SBLF) has a high concentration of dimeric 3-deoxyanthocyanidins (Geera et al., 2012). An aqueous extract from sorghum leaf sheaths has hepatoprotective and hematopoietic effects (Akande et al., 2010). In addition, it supports blood cell generation and hemoglobin-content of erythrocytes, and the leaf base also has central antinociceptive properties (Ogwumike, 2002). Spices inhibit or kill bacteria and fungi that either spoil food or harm humans and also provide micronutrients. They can be used to preserve food and they have antimicrobial properties. Some antioxidants are also found in many spices which can contribute to the body's defense against cardiovascular disease and intestinal cancers. Therefore, the addition of extracts of spices could also control the microbial activities associated with food samples while retaining the nutritive and economic quality of such foods (FAO, 2011).

NABs have been produced from plant materials having high anti-oxidant substances and significant nutrient profiles which include kunnu, sorghum stem sheath, roselle calyx and others (Devi et al., 2011). This study, therefore, adopted Response Surface Methodology (RSM) to develop and optimize the processing variables for a functional non-alcoholic beverage from roselle calyx, sorghum stem sheath, and two local spices.

\section{Materials and methods}

The raw materials used were mature reddish purple Sorghum stem sheath (poporo), roselle calyx, ginger, alligator pepper and food grade sucrose. All the materials were procured locally in Ogbomoso, southwestern Nigeria. All the reagents used for the study were of analytical grade.

\subsection{Sample preparation}

The roselle calyx and sorghum stem sheath were dusted to remove dirt and dried in the locally fabricated cabinet drier at $50^{\circ} \mathrm{C}$ for $6 \mathrm{~h}$ for moisture uniformity
(Adedeji et al., 2013). Ginger and alligator pepper were dried under the same condition for $48 \mathrm{~h}$ to a moisture content of between 10 and $12 \%$. The dried roselle calyx, sorghum stem sheath, ginger and alligator pepper were pulverized/milled into fine powdery form using a locally fabricated hammer mill. The powdered samples were packed in polythene bags before storing in airtight opaque plastic containers until when needed for analysis.

\subsection{Experimental design}

RSM was used to investigate the combined effects of significant variables (roselle calyx, sorghum stem sheath, ginger, alligator pepper, extraction temperature and time) in the production of the non-alcoholic beverage. Based on the previous studies on local non-alcoholic beverages, desirable ranges of the independent variables (factors) were selected at five coded levels $(-2,-1,0,+1,+2)$. For roselle calyx/sorghum stem sheath $\left(\mathrm{X}_{1}\right)$, two equations (Equations 1 and 2) were formulated to give the quantity of the plant materials at each of the coded levels. For ginger $\left(\mathrm{X}_{2}\right)$ and alligator pepper $\left(\mathrm{X}_{3}\right)$, the values ranged from $0.0-1.5 \mathrm{~g} / 100 \mathrm{ml}$, while extraction temperature $\left(\mathrm{X}_{4}\right)$ and extraction time $\left(\mathrm{X}_{5}\right)$ ranged from $80-100^{\circ} \mathrm{C}$ and 20 - 40 min respectively.

$$
\begin{aligned}
& \text { Roselle calyx }=\frac{\mathrm{X} \times 100}{\mathrm{X}+1} \\
& \text { Sorghum stem sheath }=\frac{100}{\mathrm{X}+1}
\end{aligned}
$$

Where $\mathrm{X}=$ The five coded levels $(-2,-1,0,+1,+2)$

The experimental design adopted was a fractional Central Composite Rotatable Design (CCRD). Table 1 gives the summary of the coded levels and real values for the fractional CCRD. The experimental runs totaling twenty-seven (27) as obtained from the design is presented in Table 2. The experiments were replicated twice for reproducibility.

The dependent variables (Y) measured were $\mathrm{VC}, \mathrm{TC}$, $\mathrm{DPPH}, \mathrm{TP}, \mathrm{pH}$, and TTA describing the quality characteristics of the non-alcoholic beverage. These dependent variables were individually expressed as a function of the independent variables known as response functions.

\subsection{The non-alcoholic beverage preparation}

Five levels were used for each spice; ginger and alligator pepper $(0,0.375,0.75,1.125,1.5 \mathrm{~g} / 100 \mathrm{ml})$ using the RSM. The processing conditions studied include extraction temperature $(80-100)^{\circ} \mathrm{C}$ and time $(20$ 40) $\min$ for the production. The various spice combinations and processing variables are presented in Table 2. The proportion of roselle calyx and sorghum 
Table 1. Coded level and real values for the CCRD experiment

\begin{tabular}{|c|c|c|c|c|c|c|}
\hline \multirow{2}{*}{ Independent variable } & \multirow{2}{*}{$\begin{array}{r}\text { Coded } \\
\text { variable }\end{array}$} & \multicolumn{5}{|c|}{ Coded levels and real values } \\
\hline & & $-\mathrm{a}$ & -1 & 0 & +1 & $+\mathrm{a}$ \\
\hline $\begin{array}{l}\text { Roselle calyx }(\mathrm{g}) \text { sorghum } \\
\text { stem sheath }(\mathrm{g})\end{array}$ & $\mathrm{X}_{1}$ & $0.000(0 / 100)$ & $\begin{array}{c}0.750 \\
(42.86 / 57.14)\end{array}$ & $1.500(60 / 40)$ & $\begin{array}{c}2.250 \\
(69.23 / 30.77)\end{array}$ & $3.000(75 / 25)$ \\
\hline Ginger (mg/100 ml) & $\mathrm{X}_{2}$ & 0.000 & 0.375 & 0.750 & 1.125 & 1.500 \\
\hline Alligator pepper $\mathrm{mg} / 100 \mathrm{ml}$ ) & $\mathrm{X}_{3}$ & 0.000 & 0.375 & 0.750 & 1.125 & 1.500 \\
\hline Extraction temperature $\left({ }^{\circ} \mathrm{C}\right)$ & $\mathrm{X}_{4}$ & 80 & 85 & 90 & 95 & 100 \\
\hline Time of extraction (min) & $\mathrm{X}_{5}$ & 20 & 25 & 30 & 35 & 40 \\
\hline
\end{tabular}

Table 2. Chemical properties of the beverage samples as affected by the processing variables

\begin{tabular}{|c|c|c|c|c|c|c|c|c|c|c|c|}
\hline \multirow{2}{*}{${ }^{\mathrm{a}}$ Run no } & \multicolumn{5}{|c|}{ Input/independent variables ${ }^{b}$} & \multicolumn{6}{|c|}{ Response/dependent variables ${ }^{\mathrm{c}}$} \\
\hline & $X_{1}$ & $X_{2}$ & $X_{3}$ & $\mathrm{X}_{4}$ & $\mathrm{X}_{5}$ & $Y_{1}$ & $Y_{2}$ & $Y_{3}$ & $Y_{4}$ & $Y_{5}$ & $Y_{6}$ \\
\hline 1 & -1 & -1 & -1 & -1 & 1 & 11.50 & 367 & 75.79 & 0.11 & 4.25 & 0.68 \\
\hline 2 & 1 & -1 & -1 & -1 & -1 & 9.52 & 1216 & 80.85 & 0.14 & 4.30 & 1.31 \\
\hline 3 & -1 & 1 & -1 & -1 & -1 & 8.86 & 472 & 68.39 & 0.11 & 4.50 & 0.99 \\
\hline 4 & 1 & 1 & -1 & -1 & 1 & 13.74 & 1456 & 64.14 & 0.18 & 4.35 & 1.85 \\
\hline 5 & -1 & -1 & 1 & -1 & -1 & 8.33 & 1124 & 68.00 & 0.13 & 4.05 & 1.04 \\
\hline 6 & 1 & -1 & 1 & -1 & 1 & 8.59 & 1368 & 74.42 & 0.15 & 4.45 & 1.35 \\
\hline 7 & -1 & 1 & 1 & -1 & 1 & 9.65 & 328 & 78.28 & 0.11 & 4.15 & 1.03 \\
\hline 8 & 1 & 1 & 1 & -1 & -1 & 10.44 & 1160 & 69.28 & 0.14 & 4.05 & 0.86 \\
\hline 9 & -1 & -1 & -1 & 1 & -1 & 10.31 & 740 & 75.71 & 0.12 & 5.60 & 2.48 \\
\hline 10 & 1 & -1 & -1 & 1 & 1 & 7.54 & 1184 & 72.50 & 0.14 & 4.45 & 2.39 \\
\hline 11 & -1 & 1 & -1 & 1 & 1 & 9.65 & 240 & 71.85 & 0.10 & 4.20 & 0.90 \\
\hline 12 & 1 & 1 & -1 & 1 & -1 & 9.25 & 201 & 74.50 & 0.09 & 4.15 & 1.36 \\
\hline 13 & -1 & -1 & 1 & 1 & 1 & 8.73 & 1064 & 60.64 & 0.13 & 4.30 & 1.08 \\
\hline 14 & 1 & -1 & 1 & 1 & -1 & 12.56 & 480 & 74.78 & 0.15 & 4.20 & 0.90 \\
\hline 15 & -1 & 1 & 1 & 1 & -1 & 11.10 & 1296 & 67.71 & 0.14 & 4.30 & 1.22 \\
\hline 16 & 1 & 1 & 1 & 1 & 1 & 8.86 & 1127 & 72.49 & 0.13 & 4.40 & 1.04 \\
\hline 17 & -2 & 0 & 0 & 0 & 0 & 10.44 & 724 & 46.79 & 0.12 & 4.50 & 0.99 \\
\hline 18 & 2 & 0 & 0 & 0 & 0 & 7.40 & 856 & 81.49 & 0.14 & 4.40 & 1.13 \\
\hline 19 & 0 & -2 & 0 & 0 & 0 & 9.91 & 1344 & 64.14 & 0.15 & 4.10 & 1.89 \\
\hline 20 & 0 & 2 & 0 & 0 & 0 & 8.86 & 752 & 85.70 & 0.12 & 4.50 & 1.62 \\
\hline 21 & 0 & 0 & -2 & 0 & 0 & 11.24 & 880 & 74.78 & 0.13 & 4.30 & 1.04 \\
\hline 22 & 0 & 0 & 2 & 0 & 0 & 15.99 & 528 & 79.56 & 0.11 & 4.10 & 1.76 \\
\hline 23 & 0 & 0 & 0 & -2 & 0 & 10.71 & 140 & 76.35 & 0.08 & 5.70 & 1.67 \\
\hline 24 & 0 & 0 & 0 & 2 & 0 & 9.91 & 424 & 64.78 & 0.11 & 4.50 & 1.22 \\
\hline 25 & 0 & 0 & 0 & 0 & -2 & 10.31 & 440 & 73.16 & 0.11 & 4.30 & 0.99 \\
\hline 26 & 0 & 0 & 0 & 0 & 2 & 11.89 & 608 & 63.50 & 0.12 & 4.20 & 1.71 \\
\hline 27 & 0 & 0 & 0 & 0 & 0 & 9.91 & 1401 & 68.00 & 0.16 & 4.40 & 1.13 \\
\hline
\end{tabular}

${ }^{a}$ Did not necessarily correspond to the order of experiment.

${ }^{b} \mathrm{X}_{1}=$ Roselle calyx/sorghum stem sheath, $\mathrm{X}_{2}=$ Ginger, $\mathrm{X}_{3}=$ Alligator pepper, $\mathrm{X}_{4}=$ Extraction temperature, $\mathrm{X}_{5}=$ Extraction time

${ }^{c} \mathrm{Y}_{1}=$ Vitamin $\mathrm{C}, \mathrm{Y}_{2}=$ Total carotenoids, $\mathrm{Y}_{3}=\mathrm{DPPH}, \mathrm{Y}_{4}=$ Total phenols, $\mathrm{Y}_{5}=\mathrm{pH}, \mathrm{Y}_{6}=\mathrm{TTA}$

These responses were in the range: $7.40-15.99 \mathrm{mg} / 100 \mathrm{ml}, 140-1456 \mathrm{mg} / 100 \mathrm{ml}, 46.79-85.70 \%, 0.08-0.18 \mathrm{mg} / 100 \mathrm{ml}, 4.05-5.70$ and $0.68-2.48 \%$ for vitamin $\mathrm{C}, \mathrm{TC}, \mathrm{DPPH}, \mathrm{TP}, \mathrm{pH}$ and TTA respectively. 
stem sheath powder to water used for the beverage formulation was 1:30, based on chemical and sensory evaluation reported by Adedeji et al. (2013).

The powdered roselle calyx, sorghum stem sheath and local spices at different proportions were mixed with an appropriate volume of water and extracted at varying temperatures and times as described in Table 2. The extract was filtered with a clean muslin cloth to obtain a clear filtrate. The filtrate was sweetened with food grade sucrose to a Brix level of $10^{\circ}$. The sweetened beverage was then dispensed into previously sterilized bottles before pasteurization at $75^{\circ} \mathrm{C}$ for $15 \mathrm{~min}$. The beverage samples were stored in the freezer $\left(-18^{\circ} \mathrm{C}\right)$ for about 8 days before analysis.

\subsection{Chemical analyses of the samples}

\subsubsection{Ascorbic acid determination}

The determination of the vitamin $\mathrm{C}$ content of the sample was carried out using the technique of iodometric titration (AOAC, 2005). This involved adding about 20 $\mathrm{ml}$ of $0.5 \mathrm{ml}$ of $\mathrm{H}_{2} \mathrm{SO}_{4}$ solution to $50 \mathrm{ml}$ of the sample, followed by the addition of the standard potassium iodide. Thereafter, about $25 \mathrm{ml}$ of the standard potassium trioxoiodate solution was pipetted into the sample solution. The ascorbic acid in the sample was analyzed by generating excess water-iodide solution. The iodine was obtained from a standard solution of potassium trioxoiodate and potassium iodide. After the ascorbic acid has reacted, the remainder was titrated with a standard thiosulphate solution. The concentration of the ascorbic acid in the sample was expressed as

$$
\frac{\mathrm{mg} \text { ascorbic acid }}{100 \mathrm{ml} \text { of sample }}
$$

\subsubsection{Determination of carotenoids by HPLC}

Carotenoids were quantified by reversed - phase HPLC (Khachik et al., 1992; Mangels et al., 1993). About $20 \mathrm{ml}$ of ethanol was added to $2 \mathrm{ml}$ of the sample already diluted with $1.8 \mathrm{ml}$ of water. After vortexing for $30 \mathrm{sec}$, the samples were extracted twice with n-hexane (1 $\mathrm{ml}$ each time, stabilized with $0.05 \%$ butylated hydroxytoluene (BHT) and vortexed for $30 \mathrm{~min}$. The supernatant was removed, cooled and evaporated under nitrogen and reconstituted with isopropanol and injected into the HPLC system.

\subsubsection{Determination of DPPH radical scavenging ability}

The free radical scavenging ability of the extracts against DPPH (1, 1- Diphenyl -2- picrylhydrazyl) free radical was evaluated as described by Gyamfi (1999).
Appropriate dilution of the extracts $(1 \mathrm{ml})$ was mixed with $1 \mathrm{ml}, 0.4 \mathrm{ml}$ methanolic solution containing DPPH radicals, the mixtures were left in the dark for $30 \mathrm{~min}$ and the absorbance measured at $516 \mathrm{~nm}$ in a spectrophotometer. The percentage DPPH free radical scavenging ability was subsequently calculated.

\subsubsection{Determination of total phenol content}

This was determined according to the method described by (Singleton et al., 1999). Appropriate dilution of the aqueous extracts was oxidized with $2.5 \mathrm{ml}$ of $10 \%$ Folin-Ciocalteau's reagent (v/v) and neutralized by $2.0 \mathrm{ml}$ of $7.5 \mathrm{ml}$ sodium carbonate. The reaction mixture was incubated for $40 \mathrm{~min}$ at $45^{\circ} \mathrm{C}$ and the absorbance was measured at $765 \mathrm{~nm}$ in the UV-Visible spectrophotometer (JENWAY 6405 Model, UK).

\subsection{5 $\mathrm{pH}$ measurement}

About $10 \mathrm{ml}$ of distilled water was added to $5 \mathrm{ml}$ of the sample and stirred. The $\mathrm{pH}$ was measured using a $\mathrm{pH}$ meter, digital model EA513 - 055, ELE, England standardized with a buffer solution of 4.0 and 7.0 (AOAC, 2005). The glass electrode of $\mathrm{pH}$ meter was dipped in about $30 \mathrm{ml}$ of the beverage sample measured into a cuvette at ambient temperature and was allowed to stabilize for sometimes after which the reading was taken.

\subsubsection{Total titratable acidity}

About $10 \mathrm{ml}$ of the beverage sample was mixed with $90 \mathrm{ml}$ of distilled water and about $0.3 \mathrm{ml}$ of indicator solution ( $1 \%$ phenolphthalein in $95 \%$ solution of ethanol) and this was titrated against $0.1 \mathrm{M}$ sodium hydroxide solution until a constant pink colour was observed. The amount of acid was calculated using the formula below.

Percentage of acid $=$ number of ml of sodium hydroxide $\mathrm{X}$ conversion factor

\subsection{Optimization procedure}

Optimization was performed on the basis of a multiple response methods called desirability. VC, TC, $\mathrm{DPPH}$, and TP were maximized, while $\mathrm{pH}$ and TTA were set in ranges. The criteria for the optimization were selected on the basis of producing a beverage with high antioxidants for health promotion. The best overall desirability which gave the expected responses corresponded to the optimum processing conditions for the beverage. The measured responses of the produced beverage in the laboratory were validated with the predicted responses at the optimum conditions. 


\subsection{Storage stability}

Samples were stored at ambient temperature $(30 \pm$ $2^{\circ} \mathrm{C}$ ) for 28 days and analyzed at 1 -week interval for the following parameters: vitamin $\mathrm{C}, \mathrm{pH}$ and TTA, Total Viable Count (TVC) and Coliform Count, CC [the method described by Harrigan (1998) was used for TVC and $\mathrm{CC}]$.

\subsection{Statistical analysis}

Experimental data from the fractional CCRD were analyzed by Analysis of Variance (ANOVA) at 95\% confidence interval using RSM to fit the quadratic polynomial equation with the Design Expert software (version 6.0.8, State-Ease, Inc., Statistics Made Easy, Minneapolis, MN).

\section{Results and discussion}

The experimental design and responses for VC, TC, DPPH, TP, pH and TTA are presented in Table 2. Vitamin $\mathrm{C}$ content was highest $(15.99 \mathrm{mg} / 100 \mathrm{ml})$ in the beverage formulation with $\mathrm{X}_{1}=1.5 \mathrm{~g}$ (RC, $60 \mathrm{~g}$, SSS, 40 g), $X_{2}=0.75 \mathrm{~g} / 100 \mathrm{ml}, X_{3}=1.5 \mathrm{~g} / 100 \mathrm{ml}, X_{4}=90^{\circ} \mathrm{C}$ and $\mathrm{X}_{5}=30 \mathrm{~min}$, while it was lowest $(7.40 \mathrm{mg} / 100 \mathrm{ml})$ in the beverage formulation of $\mathrm{X}_{1}=2.25 \mathrm{~g}(\mathrm{RC}, 69.23 \mathrm{~g}$, SSS, $30.77 \mathrm{~g}), \mathrm{X}_{2}=0.375 \mathrm{~g} / 100 \mathrm{ml}, \mathrm{X}_{3}=0.375 \mathrm{~g} / 100$ $\mathrm{ml}, \mathrm{X}_{4}=95^{\circ} \mathrm{C}$ and $\mathrm{X}_{5}=35 \mathrm{~min}$ and $\mathrm{X}_{1}=3.0 \mathrm{~g}, \mathrm{X}_{2}=0.75$ $\mathrm{g} / 100 \mathrm{ml}, \mathrm{X}_{3}=0.75 \mathrm{~g} / 100 \mathrm{ml}, \mathrm{X}_{4}=90^{\circ} \mathrm{C}$ and $\mathrm{X}_{5}=30$ min. The high value of vitamin $\mathrm{C}$ in the first beverage might be attributed to relatively high vitamin $\mathrm{C}$ content of $\mathrm{RC}$, ginger and alligator pepper. Whereas, the low concentration of ginger and alligator pepper with high extraction temperature and time could have contributed to the reduction in vitamin $\mathrm{C}$ in the second beverage sample.

This observation corroborated with the report of Ashaye et al. (2006) that vitamin C is unstable at elevated temperature. Also, vitamin $\mathrm{C}$ in solution degrades at high temperature (Spínola et al., 2013) to 3deoxythreosone. The observed decrease in vitamin $\mathrm{C}$ content may indicate degradation. The vitamin $\mathrm{C}$ content of the non-alcoholic beverage increased significantly $(\mathrm{p}<0.05)$ from $7.40-15.99 \mathrm{mg} / 100 \mathrm{ml}$, with an average value of $10.75 \mathrm{mg} / 100 \mathrm{ml}$. The average vitamin C content of the non-alcoholic beverage was higher than the value $(9.33 \mathrm{mg} / 100 \mathrm{~g})$ reported by Amoo (2006) for zobo drink. Ali et al. (2005) reported that the vitamin C status of zobo beverages can be improved by blending with spices such as ginger. Vitamin $\mathrm{C}$ also plays an important role in immune function and improves absorption of non-heme iron (Jacob and Stoudeh, 2009).
It is involved in protein metabolism and it is an important physiological antioxidant which helps to prevent molecular changes caused by oxidation ( $\mathrm{Li}$ and Schellhorn, 2007; Jacob and Stoudeh, 2009).

The total carotenoids content of the non-alcoholic beverage produced ranged from $140-1456 \mathrm{mg} / 100 \mathrm{ml}$, with an average value of $1065.78 \mathrm{mg} / 100 \mathrm{ml}$. It was observed that the total carotenoids were at the highest value of $1456 \mathrm{mg} / 100 \mathrm{ml}$ in the beverage with formulation of $X_{1}=2.25 \mathrm{~g}$ (roselle calyx, 69.23 g, Sorghum stem sheath, $30.77 \mathrm{~g}$ ), $\mathrm{X}_{2}=1.125 \mathrm{~g} / 100 \mathrm{ml}, \mathrm{X}_{3}$ $=0.375 \mathrm{~g} / 100 \mathrm{ml}, \mathrm{X}_{4}=85^{\circ} \mathrm{C}, \mathrm{X}_{5}=35 \mathrm{~min}$. The lowest value of the total carotenoids was $140 \mathrm{mg} / 100 \mathrm{ml}$ in the beverage with formulation of $\mathrm{X}_{1}=1.5 \mathrm{~g}$ (roselle calyx, $60 \mathrm{~g}$, sorghum stem sheath, $40 \mathrm{~g}$ ), $\mathrm{X}_{2}=0.75 \mathrm{~g} / 100 \mathrm{ml}$, $\mathrm{X}_{3}=0.75 \mathrm{~g} / 100 \mathrm{ml}, \mathrm{X}_{4}=80^{\circ} \mathrm{C}, \mathrm{X}_{5}=30 \mathrm{~min}$. The results showed that the total carotenoids content was enhanced at moderate extraction temperature $\left(85^{\circ} \mathrm{C}\right)$ and extraction time (35 min). Previous studies have shown the presence of carotenoids in sorghum stem sheath beverage (Rock et al., 2001; Adedeji et al., 2013).

The average carotenoids content was found to be higher than the carotenoids content reported by Adedeji et al. (2013) for sorghum stem sheath beverage spiced with ginger. Carotenoids present in sorghum stem sheath include red, yellow and orange pigments which are widely distributed in nature and serve many functions in plants life (essential for photosynthesis) and play a major role in the photo-protection of cells and tissues by neutralizing oxidant (Rock et al., 2001). The betacarotene in the sorghum stem sheath plays an essential role as the main dietary source of vitamin A, which helps eyesight (El-Sohemmy et al., 2002). Epidemiological studies provide information that carotenoids and other antioxidants may protect humans against certain types of cancer and cardiovascular diseases thus revealing its potential in promoting the health of the Nigerian populace if adopted as an indigenous beverage (Adedeji et al., 2013).

DPPH had peak value of $85.70 \%$ in the sample with $\mathrm{X}_{1}=1.5 \mathrm{~g}$ (roselle calyx, $60 \mathrm{~g}$, Sorghum stem sheath, 40 g), $X_{2}=1.5 \mathrm{~g} / 100 \mathrm{ml}, X_{3}=0.75 \mathrm{~g} / 100 \mathrm{ml}, X_{4}=90^{\circ} \mathrm{C}$ and $X_{5}=30 \mathrm{~min}$, while the lowest DPPH value of $46.79 \%$ was recorded in the sample with $X_{1}=0 \mathrm{~g}$ (roselle calyx, $0 \mathrm{~g}$, sorghum stem sheath, $100 \mathrm{~g}$ ), $\mathrm{X}_{2}=$ $0.75 \mathrm{~g} / 100 \mathrm{ml}, \mathrm{X}_{3}=0.75 \mathrm{~g} / 100 \mathrm{ml}, \mathrm{X}_{4}=90^{\circ} \mathrm{C}$ and $\mathrm{X}_{5}=$ $30 \mathrm{~min}$. This low value could be attributed to the noninclusion of roselle calyx, (which was zero) in the beverage. The DPPH radical scavenging activity of the beverage samples ranged from $46.79-85.70 \%$, with an 
average value of $67.97 \%$. The DPPH of the beverage samples were much higher than that of soymilk $7.2 \%$ (Wiwat, 2008). This observation agrees with the report of Wood and Pitler (2000) that spices have superior antioxidant capacity than many plant materials. Spices also have essential oil which is effective in scavenging free radical and has the potential to be powerful antioxidant (Colin-González et al., 2012).

Total phenols was highest value $(0.18 \mathrm{mg} / 100 \mathrm{ml})$ in sample with $\mathrm{X}_{1}=2.25 \mathrm{~g}$ (roselle calyx, 69.23 g, Sorghum stem sheath, $30.77 \mathrm{~g}$ ), $\mathrm{X}_{2}=1.125 \mathrm{~g} / 100 \mathrm{ml}, \mathrm{X}_{3}$ $=0.375 \mathrm{~g} / 100 \mathrm{ml}, \mathrm{X}_{4}=85{ }^{\circ} \mathrm{C}$ and $\mathrm{X}_{5}=35$ min while the lowest value $(0.08 \mathrm{mg} / 100 \mathrm{ml})$ was observed in sample with $\mathrm{X}_{1}=1.5 \mathrm{~g}$ (roselle calyx, $60 \mathrm{~g}$, Sorghum stem sheath, $40 \mathrm{~g}), \mathrm{X}_{2}=0.75 \mathrm{~g} / 100 \mathrm{ml}, \mathrm{X}_{3}=0.75 \mathrm{~g} / 100 \mathrm{ml}$, $\mathrm{X}_{4}=80^{\circ} \mathrm{C}$ and $\mathrm{X}_{5}=30 \mathrm{~min}$. The presence of antioxidants in roselle calyx, Sorghum stem sheath, ginger and alligator pepper must be responsible for the relatively high value.

A significant increasing trend in the total phenol content with increasing concentration of alligator pepper and ginger at moderate extraction temperature and time was observed. This observation confirmed earlier report that spices have the superior antioxidant capacity to berries, other fruits, vegetables and nuts (Wood and Pitler, 2000). Phenolics were identified as components with the strongest antioxidant capacity in fruits, vegetables, and mushrooms (Heo et al., 2007). Jacob Velzquez and Isneros- zevallos (2009) reported that total phenolic contents of carrots under different storages had a linear relationship with the anti-oxidant activities.

The $\mathrm{pH}$ value was highest (5.7) in the beverage formulation with $\mathrm{X}_{1}=1.5 \mathrm{~g}(\mathrm{RC}, 60 \mathrm{~g}$, SSS, $40 \mathrm{~g}), \mathrm{X}_{2}=$ $0.75 \mathrm{~g} / 100 \mathrm{ml}, \mathrm{X}_{3}=0.75 \mathrm{~g} / 100 \mathrm{ml}, \mathrm{X}_{4}=80{ }^{\circ} \mathrm{C}$ and $\mathrm{X}_{5}=$ $30 \mathrm{~min}$, while the sample with the lowest $\mathrm{pH}(4.05)$ was noted in the formulation with $\mathrm{X}_{1}=2.25 \mathrm{~g}(\mathrm{RC}, 69.23 \mathrm{~g}$, SSS, $30.77 \mathrm{~g}), \mathrm{X}_{2}=1.125 \mathrm{~g} / 100 \mathrm{ml}, \mathrm{X}_{3}=1.125 \mathrm{~g} / 100$ $\mathrm{ml}, \mathrm{X}_{4}=85^{\circ} \mathrm{C}$ and $\mathrm{X}_{5}=25 \mathrm{~min}$. It was observed that the $\mathrm{pH}$ of the beverage samples decreased with increase in the concentration of $\mathrm{RC}$, ginger, and $\mathrm{AP}$, while the increase in the concentration of SSS increased the $\mathrm{pH}$ of the beverage. A decrease in $\mathrm{pH}$ is synonymous to increase in acidity (Ade-Omowaye et al., 2015). The low $\mathrm{pH}$ could be attributed to the effect of $\mathrm{RC}$ extract which has been reported to be very acidic (Oluwaniyi, 2009).

The beverage samples had an average $\mathrm{pH}$ of 4.4. Fasoyiro et al. (2005) reported that the $\mathrm{pH}$ of RC drink ranged from 2.19 to 3.62. Oluwaniyi (2009) also reported that the $\mathrm{pH}$ of zobo drink ranged from 1.6 to 2.7, while SSS drink ranged from 6.2 to 8.4. Majority of
NABs contain high concentrations of simple carbohydrates, preserving agents, which make the product acidic; which could afterward exact a negative impact on health and well-being. The $\mathrm{pH}$ of zobo drink was reported to range from 3.13 to 3.28 (Bolade et al., 2009), while carrot - orange drink was 2.5 to 5.0 (Karangwa et al., 2010). However, the $\mathrm{pH}$ of the formulated beverage sample showed that the beverage could be a suitable alternative or substitute for acidic NABs.

TTA was highest (2.48\%) in the beverage formulation with $\mathrm{X}_{1}=0.75 \mathrm{~g}(\mathrm{RC}, 42.86 \mathrm{~g}, \mathrm{SSS}, 57.14$ g), $X_{2}=0.375 \mathrm{~g} / 100 \mathrm{ml}, X_{3}=0.375 \mathrm{~g} / 100 \mathrm{ml}, X_{4}=95^{\circ} \mathrm{C}$ and $\mathrm{X}_{5}=25 \mathrm{~min}$. It was very low $(0.68 \%)$ in the beverage formulation with $\mathrm{X}_{1}=0.75 \mathrm{~g}$ ( $\mathrm{RC}, 42.86 \mathrm{~g}$, SSS, $57.14 \mathrm{~g}), X_{2}=0.375 \mathrm{~g} / 100 \mathrm{ml}, \mathrm{X}_{3}=0.375 \mathrm{~g} / 100$ $\mathrm{ml}, \mathrm{X}_{4}=85^{\circ} \mathrm{C}$ and $\mathrm{X}_{5}=35 \mathrm{~min}$, depicting increase in TTA with increased extraction temperature. An average TTA of $1.24 \%$ was obtained, which was slightly higher than the prescribed range $(0.39-1.1 \%)$ for NABs. The TTA of cooked ginger drink was reported to be $0.52 \%$, while that of uncooked ginger drink was $0.21 \%$ (Hazarika et al., 2013).

Tables $3-7$ show the ANOVA results to establish predictive models (equations 5 - 10) for the responses measured in the non-alcoholic beverage obtained from the various levels of the processing variables. The response surface plots in 3 dimensions showing the effect of roselle calyx/sorghum stem sheath and extraction time on the non-alcoholic beverage is shown in Figures 1 and 2.

Positive sign in front of the factors in equations 5 10 signifies a synergistic effect, while negative sign signifies an antagonistic effect. The positive factors are important parameters responsible for increasing each of the responses and vice versa.

\subsection{Optimization}

The optimum conditions for independent variables and the predicted values of the responses were as follows: RC/SSS, $66.67 \mathrm{~g} / 33.33 \mathrm{~g}$; ginger, $0.375 \mathrm{~g} / 100$ $\mathrm{ml}$; AP, $0.375 \mathrm{~g} / 100 \mathrm{ml}$; ET, $85^{\circ} \mathrm{C}$; and TOE, $35 \mathrm{~min}$, and $11.32,1472,0.16(\mathrm{mg} / 100 \mathrm{ml})$, and $73.24 \%$ for $\mathrm{VC}, \mathrm{TC}$, TP and DPPH respectively. A verification experiment at the optimum conditions, consisting of 3 runs, was performed and the measured responses were 15.33, $1757.2,0.31(\mathrm{mg} / 100 \mathrm{ml})$ and $89.21 \%$ for $\mathrm{VC}, \mathrm{TC}, \mathrm{TP}$, and DPPH respectively. These results of the conducted experiments showed that these optimized conditions can be used for the beverage production yielding high values 
Table 3. Analysis of variance for vitamin C

\begin{tabular}{cccccc}
\hline Variable & $\begin{array}{c}\text { Sum of } \\
\text { Square }\end{array}$ & $\begin{array}{c}\mathrm{D} \\
\mathrm{O}\end{array}$ & $\begin{array}{c}\text { Mean } \\
\text { Square }\end{array}$ & $\begin{array}{c}\mathrm{F} \\
\text { value }\end{array}$ & Prob. $>\mathrm{F}$ \\
\hline Model & 172.31 & 25 & 6.89 & 26.78 & $<0.0001^{*}$ \\
$\mathrm{X}_{1}$ & 3.25 & 1 & 3.25 & 12.61 & $0.0014^{*}$ \\
$\mathrm{X}_{2}$ & 3.41 & 1 & 3.41 & 13.25 & $0.0011^{*}$ \\
$\mathrm{X}_{3}$ & 5.24 & 1 & 5.24 & 20.38 & $0.0001^{*}$ \\
$\mathrm{X}_{4}$ & 0.38 & 1 & 0.38 & 1.46 & 0.2368 \\
$\mathrm{X}_{5}$ & 1.51 & 1 & 1.51 & 5.86 & $0.0222^{*}$ \\
$\mathrm{X}_{1} \mathrm{X}_{2}$ & 1.71 & 1 & 1.71 & 6.63 & $0.0156^{*}$ \\
$\mathrm{X}_{1} \mathrm{X}_{4}$ & 3.84 & 1 & 3.84 & 14.93 & $0.0006^{*}$ \\
$\mathrm{X}_{1} \mathrm{X}_{5}$ & 1.98 & 1 & 1.98 & 7.67 & $0.0098^{*}$ \\
$\mathrm{X}_{2} \mathrm{X}_{4}$ & 3.16 & 1 & 3.16 & 12.26 & $0.0016^{*}$ \\
$\mathrm{X}_{2} \mathrm{X}_{5}$ & 5.45 & 1 & 5.45 & 21.19 & $<0.0001^{*}$ \\
$\mathrm{X}_{3} \mathrm{X}_{4}$ & 15.39 & 1 & 15.39 & 59.79 & $<0.0001^{*}$ \\
$\mathrm{X}_{3} \mathrm{X}_{5}$ & 15.39 & 1 & 15.39 & 59.79 & $<0.0001^{*}$ \\
$\mathrm{X}_{4} \mathrm{X}_{5}$ & 27.36 & 1 & 27.36 & 106.31 & $<0.0001^{*}$ \\
Residual & 7.21 & 28 & 0.26 & & \\
Lack of Fit & 6.3 & 1 & 6.3 & 186.7 & $<0.0001$ \\
Pure Error & 0.91 & 27 & 0.034 & & \\
Cor Total & 179.52 & 53 & & & \\
\hline DOF Deg & & & & &
\end{tabular}

$\mathrm{DOF}=$ Degrees of Freedom

$\mathrm{R}^{2}=0.9599 ;$ Adj $\mathrm{R}^{2}=0.9240$; Pred $\mathrm{R}^{2}=0.8598$

For coded factors: $\mathrm{X}_{1}=$ Hibiscus sabdariffa and Sorghum Stem Sheath, $\mathrm{X}_{2}=$ Ginger, $\mathrm{X}_{3}=$ Alligator pepper, $\mathrm{X}_{4}=$ Extraction temperature, $\mathrm{X}_{5}=$ Extraction time

*Significant at $95 \%$ confidence level
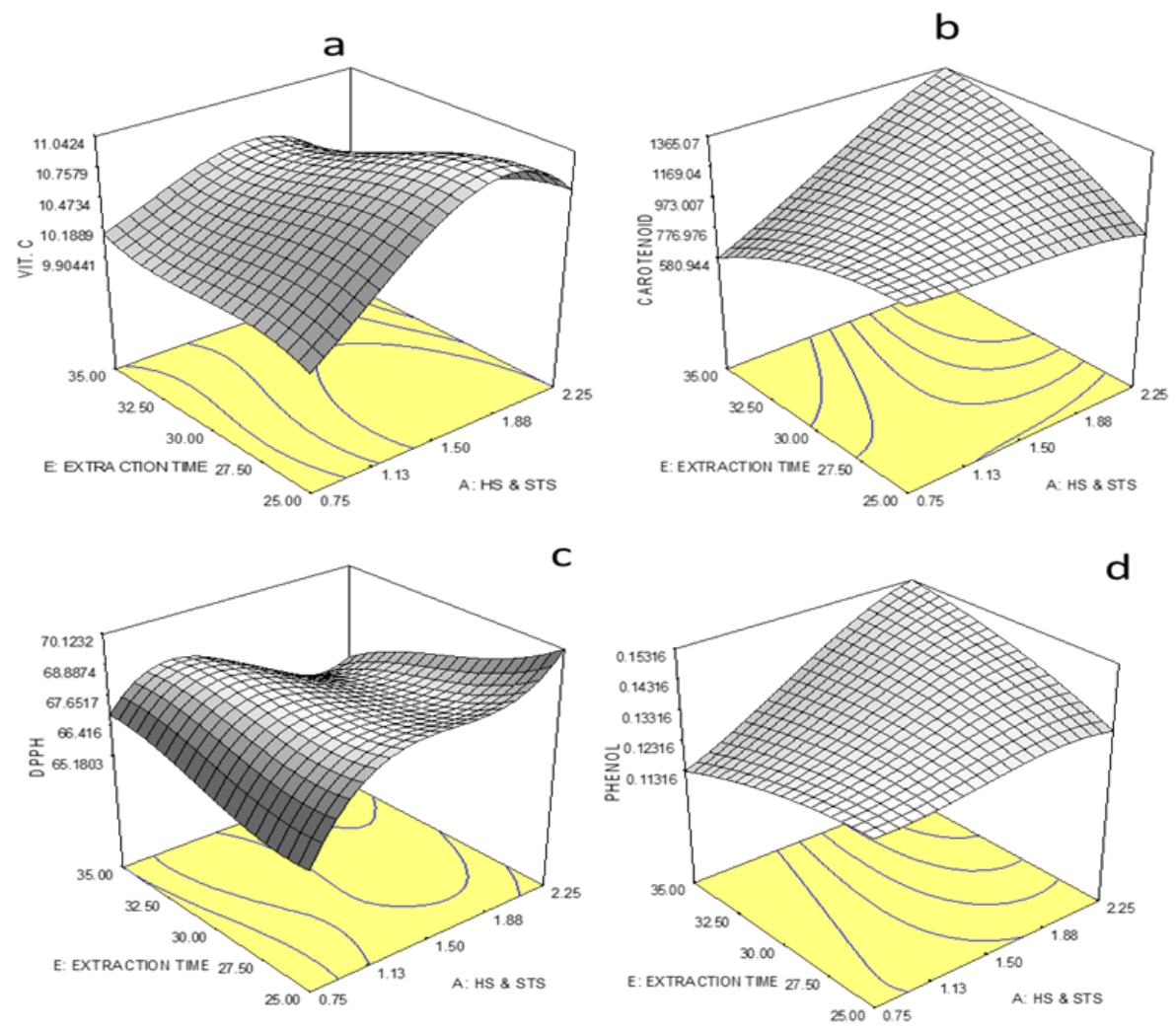

Table 4. Analysis of variance for total carotenoids

\begin{tabular}{cccccc}
\hline Variables & $\begin{array}{c}\text { Sum of } \\
\text { Square }\end{array}$ & $\begin{array}{c}\mathrm{D} \\
\mathrm{O} \\
\mathrm{F}\end{array}$ & $\begin{array}{c}\text { Mean } \\
\text { Square }\end{array}$ & $\begin{array}{c}\mathrm{F} \\
\text { value }\end{array}$ & Prob. $>\mathrm{F}$ \\
\hline Model & 8021000 & 25 & 320900 & 8.59 & $<0.0001^{*}$ \\
$\mathrm{X}_{1}$ & 655600 & 1 & 655600 & 17.55 & $0.0003^{*}$ \\
$\mathrm{X}_{3}$ & 652900 & 1 & 652900 & 17.48 & $0.0003^{*}$ \\
$\mathrm{X}_{4}$ & 231400 & 1 & 231400 & 6.19 & $0.019^{*}$ \\
$\mathrm{X}_{1} \mathrm{X}_{3}$ & 458400 & 1 & 458400 & 12.27 & $0.0016^{*}$ \\
$\mathrm{X}_{1} \mathrm{X}_{4}$ & 1327000 & 1 & 1327000 & 35.52 & $<0.0001^{*}$ \\
$\mathrm{X}_{1} \mathrm{X}_{5}$ & 1722000 & 1 & 1722000 & 46.1 & $<0.0001^{*}$ \\
$\mathrm{X}_{3} \mathrm{X}_{4}$ & 160500 & 1 & 160500 & 4.3 & $0.0475^{*}$ \\
$\mathrm{X}_{4} \mathrm{X}_{5}$ & 228500 & 1 & 228500 & 6.12 & $0.0197^{*}$ \\
Residual & 1046000 & 28 & 37358.8 & & \\
Lack of & 1011000 & 1 & 1011000 & 787.37 & $<0.0001$ \\
Fit & & & & & \\
Pure Error & 34681 & 27 & 1284.48 & & \\
Cor Total & 9067000 & 53 & & & \\
\hline
\end{tabular}

DOF $=$ Degrees of Freedom

$\mathrm{R}^{2}=0.8846$; Pred. $\mathrm{R}^{2}=0.7816$; Adj. $\mathrm{R}^{2}=0.6001$

For coded factors: $\mathrm{X}_{1}=$ Hibiscus sabdariffa and Sorghum Stem Sheath, $\mathrm{X}_{2}=$ Ginger, $\mathrm{X}_{3}=$ Alligator pepper, $\mathrm{X}_{4}=$ Extraction temperature, $\mathrm{X}_{5}=$ Extraction time

*Significant at $95 \%$ confidence level 
Table 5. Analysis of variance for DPPH

\begin{tabular}{|c|c|c|c|c|c|}
\hline $\begin{array}{l}\text { Input } \\
\text { variable }\end{array}$ & $\begin{array}{l}\text { Sum of } \\
\text { Squares }\end{array}$ & $\begin{array}{l}\mathrm{D} \\
\mathrm{O} \\
\mathrm{F}\end{array}$ & $\begin{array}{c}\text { Mean } \\
\text { Square }\end{array}$ & $\begin{array}{c}\mathrm{F} \\
\text { value }\end{array}$ & Prob. $>\mathrm{F}$ \\
\hline Model & 3203.54 & 25 & 128.14 & 349.69 & $<0.0001^{*}$ \\
\hline $\mathrm{X}_{1}$ & 36.14 & 1 & 36.14 & 98.62 & $<0.0001 *$ \\
\hline$X_{2}$ & 156.38 & 1 & 156.38 & 426.74 & $<0.0001 *$ \\
\hline $\mathrm{X}_{3}$ & 57.91 & 1 & 57.91 & 158.04 & $<0.0001 *$ \\
\hline $\mathrm{X}_{1} \mathrm{X}_{2}$ & 100.15 & 1 & 100.15 & 273.29 & $<0.0001 *$ \\
\hline $\mathrm{X}_{1} \mathrm{X}_{3}$ & 32.10 & 1 & 32.10 & 87.60 & $<0.0001 *$ \\
\hline $\mathrm{X}_{1} \mathrm{X}_{4}$ & 50.18 & 1 & 50.18 & 136.93 & $<0.0001 *$ \\
\hline $\mathrm{X}_{1} \mathrm{X}_{5}$ & 63.42 & 1 & 63.42 & 173.08 & $<0.0001 *$ \\
\hline $\mathrm{X}_{2} \mathrm{X}_{3}$ & 160.43 & 1 & 160.43 & 437.80 & $<0.0001 *$ \\
\hline $\mathrm{X}_{2} \mathrm{X}_{4}$ & 59.49 & 1 & 59.49 & 162.34 & $<0.0001 *$ \\
\hline $\mathrm{X}_{2} \mathrm{X}_{5}$ & 65.87 & 1 & 65.87 & 179.75 & $<0.0001 *$ \\
\hline $\mathrm{X}_{3} \mathrm{X}_{4}$ & 49.08 & 1 & 49.08 & 133.93 & $<0.0001 *$ \\
\hline $\mathrm{X}_{3} \mathrm{X}_{5}$ & 56.84 & 1 & 56.84 & 155.13 & $<0.0001 *$ \\
\hline $\mathrm{X}_{4} \mathrm{X}_{5}$ & 56.42 & 1 & 56.42 & 153.96 & $<0.0001 *$ \\
\hline Residual & 10.26 & 28 & 0.37 & & \\
\hline $\begin{array}{l}\text { Lack of } \\
\text { Fit }\end{array}$ & 0.017 & 1 & 0.017 & 0.045 & 0.8334 \\
\hline $\begin{array}{l}\text { Pure } \\
\text { Error }\end{array}$ & 10.24 & 27 & 0.38 & & \\
\hline Cor Total & 3213.80 & 53 & & & \\
\hline
\end{tabular}

DOF $=$ Degrees of Freedom

$\mathrm{R}^{2}=0.9968$; Pred. $\mathrm{R}^{2}=0.9940 ;$ Adj. $\mathrm{R}^{2}=0.9876$

For coded factors: $\mathrm{X}_{1}=$ Hibiscus sabdariffa and Sorghum Stem Sheath, $\mathrm{X}_{2}=$ Ginger, $\mathrm{X}_{3}=$ Alligator pepper, $\mathrm{X}_{4}=$ Extraction temperature, $\mathrm{X}_{5}=$ Extraction time

*Significant at $95 \%$ confidence level

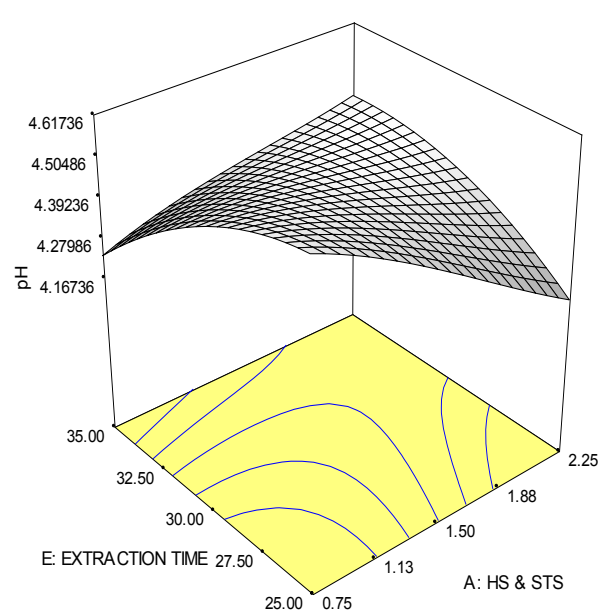

a

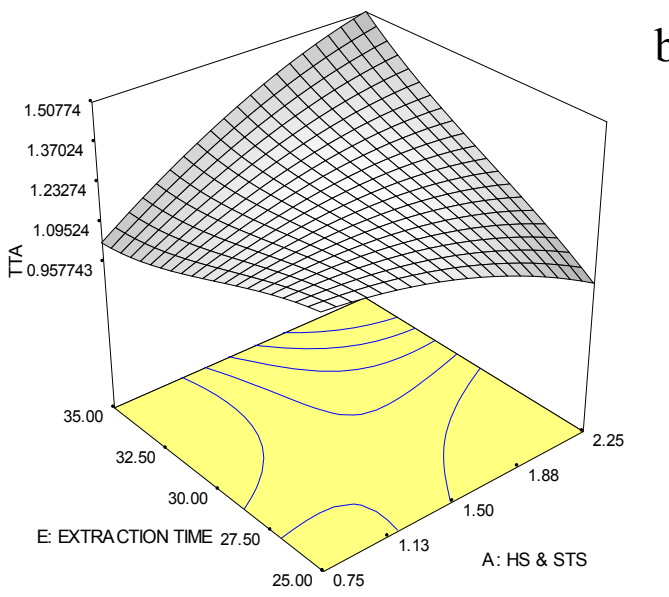

b

Figure 2. Response surface plots for the interaction of Roselle calyx/Sorghum stem sheath and extraction time $\left(\mathrm{X}_{1} \mathrm{X}_{5}\right)$ on the (a) $\mathrm{pH}(\mathrm{b})$ TTA

Table 6. Analysis of variance for total phenols

\begin{tabular}{lccccc}
\hline \multicolumn{1}{c}{$\begin{array}{c}\text { Input } \\
\text { variable }\end{array}$} & Sum of Squares & $\begin{array}{c}\text { Degrees of } \\
\text { Freedom }\end{array}$ & Mean Square & F value & Prob. $>$ F \\
\hline Model & 0.020 & 25 & $7.977 \mathrm{E}-004$ & 6.01 & $<0.00016^{*}$ \\
$\mathrm{X}_{1}$ & $3.403 \mathrm{E}-003$ & 1 & $3.403 \mathrm{E}-003$ & 25.63 & $<0.0001^{*}$ \\
$\mathrm{X}_{3}$ & $1.736 \mathrm{E}-003$ & 1 & $1.736 \mathrm{E}-003$ & 13.08 & $0.0012^{*}$ \\
$\mathrm{X}_{1} \mathrm{X}_{4}$ & $1.953 \mathrm{E}-003$ & 1 & $1.953 \mathrm{E}-003$ & 14.71 & $0.0007^{*}$ \\
$\mathrm{X}_{1} \mathrm{X}_{5}$ & $2.628 \mathrm{E}-003$ & 1 & $2.628 \mathrm{E}-003$ & 19.80 & $0.0001^{*}$ \\
$\mathrm{X}_{2} \mathrm{X}_{4}$ & $7.031 \mathrm{E}-004$ & 1 & $7.031 \mathrm{E}-004$ & 5.30 & $0.0290^{*}$ \\
$\mathrm{X}_{3} \mathrm{X}_{4}$ & $1.653 \mathrm{E}-003$ & 1 & $1.653 \mathrm{E}-003$ & 12.45 & $0.0015^{*}$ \\
$\mathrm{X}_{3} \mathrm{X}_{5}$ & $1.128 \mathrm{E}-003$ & 1 & $1.128 \mathrm{E}-003$ & 8.50 & $0.0069^{*}$ \\
Residual & $3.717 \mathrm{E}-003$ & 28 & $1.328 \mathrm{E}-004$ & & $<0.0001$ \\
Lack of Fit & $3.117 \mathrm{E}-003$ & 1 & $3.117 \mathrm{E}-003$ & 140.28 & \\
Pure Error & $6.000 \mathrm{E}-004$ & 27 & $2.222 \mathrm{E}-005$ & & \\
Cor Total & 0.024 & 53 & & & \\
\hline
\end{tabular}

$\mathrm{R}^{2}=0.8429$; Pred. $\mathrm{R}^{2}=0.7026 ;$ Adj. $\mathrm{R}^{2}=0.4513$

For coded factors: $\mathrm{X}_{1}=$ Hibiscus sabdariffa and Sorghum Stem Sheath, $\mathrm{X}_{2}=$ Ginger, $\mathrm{X}_{3}=$ Alligator pepper, $\mathrm{X}_{4}=$ Extraction temperature, $\mathrm{X}_{5}=$ Extraction time

*Significant at $95 \%$ confidence level 


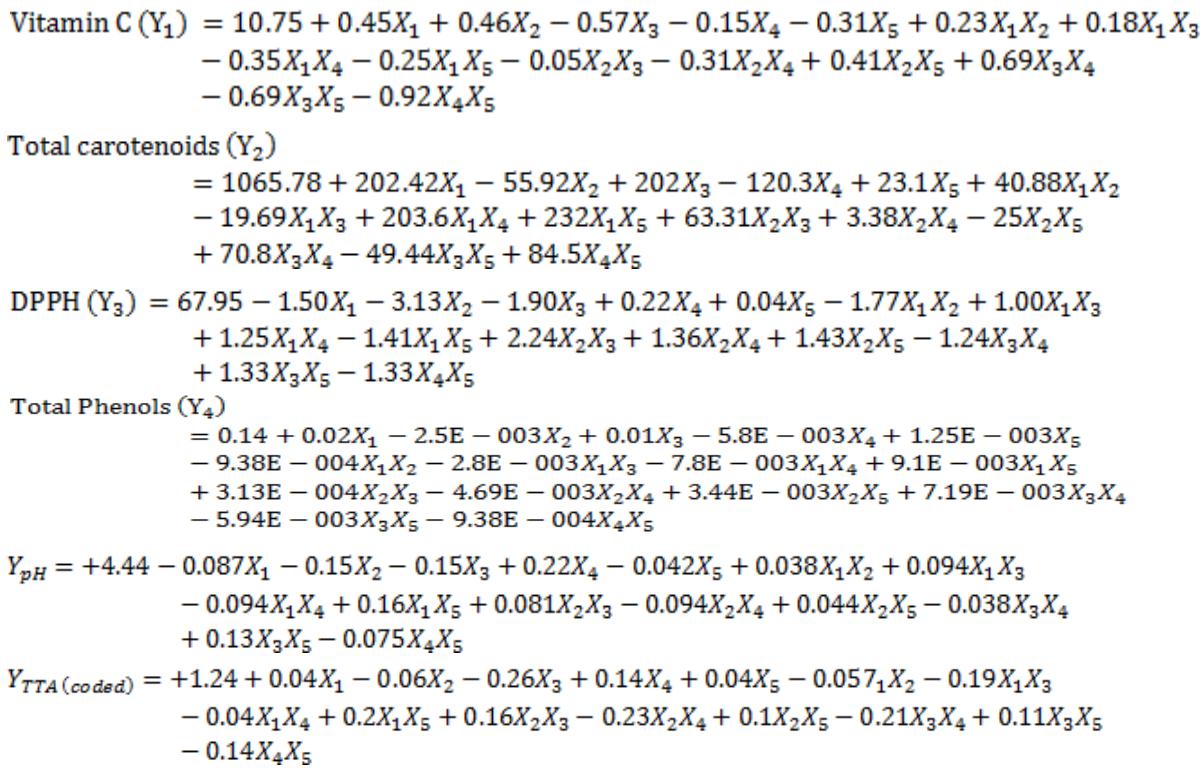

Table 7. Analysis of variance for TTA

\begin{tabular}{|c|c|c|c|c|c|}
\hline $\begin{array}{c}\text { Input } \\
\text { variable }\end{array}$ & $\begin{array}{l}\text { Sum } \\
\text { of } \\
\text { Squar } \\
\text { es }\end{array}$ & $\begin{array}{l}\mathrm{D} \\
\mathrm{O} \\
\mathrm{F}\end{array}$ & $\begin{array}{l}\text { Mean } \\
\text { Square }\end{array}$ & F value & Prob.> F \\
\hline Model & 11.48 & 25 & 0.46 & 43.34 & $<0.00018$ \\
\hline $\mathrm{X}_{1}$ & 0.028 & 1 & 0.028 & 2.62 & 0.1166 \\
\hline $\mathrm{X}_{2}$ & 0.057 & 1 & 0.057 & 5.36 & $0.0281^{*}$ \\
\hline $\mathrm{X}_{3}$ & 1.11 & 1 & 1.11 & 104.37 & $<0.0001 *$ \\
\hline $\mathrm{X}_{4}$ & 0.33 & 1 & 0.33 & 30.84 & $<0.0001^{*}$ \\
\hline $\mathrm{X}_{1} \mathrm{X}_{2}$ & 0.064 & 1 & 0.064 & 6.03 & $0.0205^{*}$ \\
\hline$X_{1} X_{3}$ & 1.17 & 1 & 1.17 & 110.82 & $<0.0001^{*}$ \\
\hline $\mathrm{X}_{1} \mathrm{X}_{4}$ & 0.049 & 1 & 0.049 & 4.61 & $0.0406^{*}$ \\
\hline $\mathrm{X}_{1} \mathrm{X}_{5}$ & 1.31 & 1 & 1.31 & 123.45 & $<0.0001^{*}$ \\
\hline $\mathrm{X}_{2} \mathrm{X}_{3}$ & 0.79 & 1 & 0.79 & 74.61 & $<0.0001^{*}$ \\
\hline $\mathrm{X}_{2} \mathrm{X}_{4}$ & 1.70 & 1 & 1.70 & 160.19 & $<0.0001 *$ \\
\hline $\mathrm{X}_{2} \mathrm{X}_{5}$ & 0.33 & 1 & 0.33 & 30.77 & $<0.0001 *$ \\
\hline $\mathrm{X}_{3} \mathrm{X}_{4}$ & 1.39 & 1 & 1.39 & 131.20 & $<0.0001 *$ \\
\hline $\mathrm{X}_{3} \mathrm{X}_{5}$ & 0.41 & 1 & 0.41 & 38.43 & $<0.0001 *$ \\
\hline $\mathrm{X}_{4} \mathrm{X}_{5}$ & 0.64 & 1 & 0.64 & 59.98 & $<0.0001 *$ \\
\hline Residual & 0.30 & 28 & 0.011 & & \\
\hline $\begin{array}{l}\text { Lack of } \\
\text { Fit }\end{array}$ & 0.12 & 1 & 0.12 & 17.94 & 0.0002 \\
\hline $\begin{array}{l}\text { Pure } \\
\text { Error }\end{array}$ & 0.18 & 27 & $\begin{array}{c}6.602 \mathrm{E}- \\
003\end{array}$ & & \\
\hline $\begin{array}{l}\text { Cor } \\
\text { Total }\end{array}$ & 11.78 & 53 & & & \\
\hline
\end{tabular}

DOF $=$ Degrees of Freedom

$\mathrm{R}^{2}=0.9748$; Pred. $\mathrm{R}^{2}=0.9523$; Adj. $\mathrm{R}^{2}=0.9098$

For coded factors: $\mathrm{X}_{1}=$ Hibiscus sabdariffa and Sorghum Stem Sheath, $X_{2}=$ Ginger, $X_{3}=$ Alligator pepper, $X_{4}=$ Extraction temperature, $\mathrm{X}_{5}=$ Extraction time

*Significant at $95 \%$ confidence interval for the responses. A correlation of the predicted and measured responses gave a high $\mathrm{R}^{2}$ of 0.9999 (Figure 3).

\subsection{Storage stability of the beverage samples}

The result of the storage study is presented in Table 8. The value of TTA increased progressively while $\mathrm{pH}$ and vitamin $\mathrm{C}$ content decreased gradually as storage period progressed. There was a reduction in vitamin $\mathrm{C}$ from 14.82 to $12.69 \mathrm{mg} / 100 \mathrm{ml}$ during the 4 th week of the storage period. This reduction could be attributed to the nutrient depletion and the effect of a by-product of metabolism on food items as reported by Nwafor and Ogiehor (2003) and possible utilization by associated microorganisms, bioconversion into organic acids and other organic compounds. Similar observations have been reported for related food items by Omobuwajo et al. (1993). These may partly explain the significant decrease in $\mathrm{pH}$ as storage period progressed which is also an indication of increased acidity. A similar trend was reported for TTA in SSS beverage by AdeOmowaye et al. (2015).

The results of the microbial analysis showed that there were no observable bacteria and coliform growths in the fresh beverage. This is an indication that the beverage was produced hygienically. Bacterial growth was detected in the beverage after the first two weeks $\left(1.0 \times 10^{2} \mathrm{CFU} / \mathrm{ml}\right)$ and it increased $\left(7.0 \times 10^{2} \mathrm{CFU} / \mathrm{ml}\right)$ after the 4 th week. The microbial load obtained after the 4th week of storage is within the safe limits of $1.0 \times 10^{5}$ CFU/ml (Ogbuile et al., 2005).

Samples of roselle calyx liquor and sorghum bicolor treated with $1.0 \%$ Aframomum melegueta had average microbial loads of 3.70 and $4.10 \times 10^{2} \mathrm{CFU} / \mathrm{ml}$, respectively (Oluwalana and Adedeji, 2014). Result obtained has shown a clear trend of microbial growth 


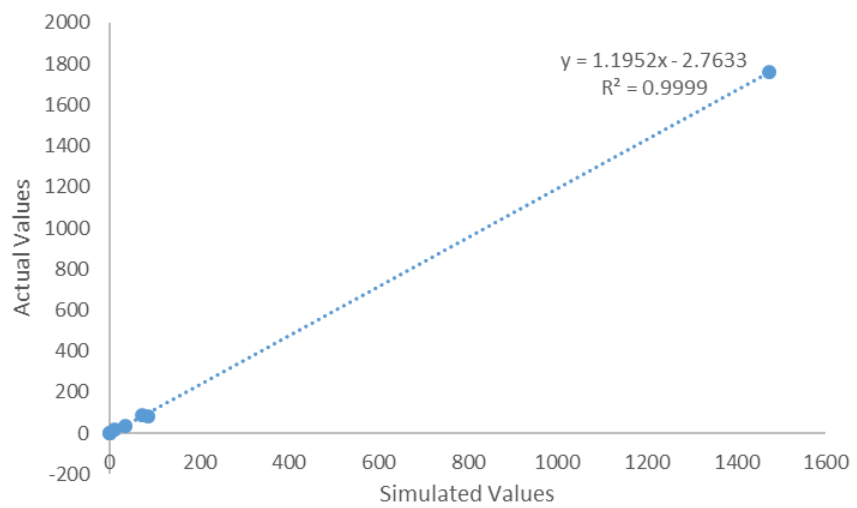

Figure 3. Graph of predicted optimized sample against actual experimental values

Table 8. Effect of storage time on the optimized beverage sample

\begin{tabular}{lccccc}
\hline \multicolumn{1}{c}{ Parameter } & Week & Week & Week & Week & Week \\
& 0 & 1 & 2 & 3 & 4 \\
\hline $\mathrm{pH}$ & 4.19 & 4.19 & 3.11 & 2.81 & 2.66 \\
$\mathrm{Vit} \mathrm{C}(\mathrm{mg} / 100$ & 14.82 & 13.21 & 13.09 & 12.92 & 12.69 \\
$\mathrm{ml})$ & & & & & \\
$\mathrm{TTA}(\%)$ & 1.70 & 1.98 & 2.97 & 3.50 & 5.09 \\
Total viable & & & & & \\
$\begin{array}{l}\text { count }(\mathrm{CFU} / \mathrm{ml}) \\
\mathrm{x} 10^{2}\end{array}$ & - & - & 1 & 2 & 7 \\
$\begin{array}{l}\text { Total coliform } \\
\text { count }(\mathrm{CFU} / \mathrm{ml})\end{array}$ & - & - & - & & \\
$\mathrm{x} 10^{2}$ & & & & & - \\
\hline
\end{tabular}

suppression with an increase in the percentage of inclusion of natural preservatives to the beverage samples (Power et al., 1995). The addition of ginger and alligator pepper to the beverage produced showed that the spices have antimicrobial activity. Ginger extract has been shown to elongate the shelf life of roselle calyx and sorghum bicolor liquor from two to four weeks (Adegoke and Skura, 1994). Ginger has been shown to possess anti-tumor, anti-proliferative, antihypertensive, bactericidal and nematocidal properties due to its 6gingerol, 6-paradol, shagaols and zingiberene contents (Ben-Nwadia et al., 2005).

Similar findings have been documented for roselle calyx drink (Ogiehor et al., 2008) in which shelf-life was extended by a period of two weeks with the inclusion of $0.2 \%$ ginger extract. There was no coliform growth in the beverage throughout the period of storage.

\section{Conclusion}

RSM was successfully applied to optimize the processing variables for the production of a nonalcoholic beverage from roselle calyx, Sorghum stem sheath, and two local spices. The processing variables employed in this study had a great effect on the quality of the beverage. To a certain level, the vitamin $\mathrm{C}$, total carotenoids, DPPH and total phenols increased. Modeling of experimental data allowed the generation of useful equations for later usage, in order to predict the behavior of the system under different factor combinations.

\section{Acknowledgements}

The authors are grateful to Dr. O.O. Ogunleye for the assistance proffered in the experimental design. TETFund is also acknowledged for financial support.

\section{References}

Adedeji, T.O., Oluwalana, I.B. and Ade-Omowaye, B.I.O. (2013). Investigation on antioxidant and antinutritional properties of sorghum stem sheath-ginger extract based non-alcoholic beverage. International Journal of Food Science and Nutrition Engineering, 3(3), 28-34.

Akande, I.S, Oseni, A.A, and Biobaku, O.A. (2010). Effects of aqueous extract of Sorghum bicolor on hepatic, histological and haematological indices in rats. Journal of Cell Animal Biology, 4, 137-142.

Ali, B.H., Al-Wabel, N. and Blunden, G. (2005). Phytochemical, pharmacological and toxicological aspects of Hibiscus sabdariffa L.: A review. Phototherapy Research. 19(5), 369-375.

Amoo, I.A. (2006). Characterization of the extract of calyces of Roselle as a source of "zobo" drink in Nigeria. Natural Phytochemistry, (1), 56-58.

AOAC. (2005). Official Methods of Analysis, $22^{\text {nd }}$ ed. Washington DC, USA: Association of Analytical Chemist.

Ashaye, O.A., Taiwo, O.O. and Adegoke, G.O. (2006). Effect of local preservative (Aframomum danielli) on the chemical and sensory properties of stored warankasi. African Journal of Agriculture Resolvement, 1, 10-16.

Bagchi, D., Bagchi, M., Stoh, S.J., Das, D.K., Ray, S.D. and Kuszynski, C.A. (2000). Free radicals and grape seed proanthocyanidin extract: Importance in human health anddisease prevention. Toxicology, 148, 187-197.

Colin-González, A.L., Santana, R.A., Silva-Islas, C.A., Chánez-Cárdenas, M.E., Santamaria, A. and Maldonado, P.D. (2012), The Antioxidant Mechanisms Underlying the Aged Garlic Extractand S-Allylcysteine-Induced Protection. Oxidative Medicine and Cellular Longevity (2012). http:// dx.doi.org/10.1155/2012/907162 
Devi, P.S., Kumar, M.S. and Das, S.M. (2011). Evaluation of anti-proliferative activity of red sorghum bran anthocyanin on a human breast cancer cell line (mcf-7). International Journal of Breast Cancer, $2011 . \quad \mathrm{http}: / /$ dx.doi.org/10.4061/2011/891481

Dharmasena, K.A. (2010). The Non-Alcoholic Beverage Market in the United States: Demand Interrelationships, Dynamics, Nutrition Issues and Probability Forecast Evaluation. US: Texas A and M University, PhD Thesis

EFSA. (2011). European Food Safety Authority. The setting of nutrient profiles for foods bearing nutrition and health claims pursuant to Article of the Regulation (EC) No 1924/2006: Scientific Opinion of the Panel on Dietetic Products, Nutrition and Allergies. Retrieved on February 2011 from ESFA website: http://www.efsa.europa.eu/en/efsajournal/ doc/644.pdf

El-Sohemmy, A., Balyin Akabkmigbe, E., Asheria, A., Spiegelman, D. and Campos. (2002). Individual carotenoids concentration in adipose tissue and plasma as biomarkers of dietary intake. American Journal of Clinical Nutrition, 76, 172-179.

FAO. (2011). Processing for prosperity, FAO Diversification booklet No. 5. 2nd ed. Rome: FAO.

Geera, B., Ojwang, L.O, and Awika, J.M. (2012). New highly stable dimeric 3-deoxyanthocyanidin pigments from Sorghum bicolor leaf sheath. Journal of Food Science, 77, C566-C572.

Gyamfi, M.A., Yonamine, M. and Aniya, Y. (1999). Free radical scavenging activity of medicinal herb of Ghana: Thonningia sanguinea on experimentally induced liver injuries, General Pharmacology, 32, 661-667.

Heo, H.J., Kim, Y.J. Chung, D. and Kim D.O. (2007) Antioxidant capacities of Individual and combined phenolics in a model system. Journal of Food Chemistry, 104, 87-92.

Jacob -Velzquez, D.A. and Isneros-Zevallos, L. (2009). Correlations of antioxidant activity against phenolic content revisited a new approach in data analysis for food and medicinal plants. Journal of Food Science, 74, R107-R113.

Jacob, R.A. and Stoudeh, G. (2009). Vitamin C function and Status in Chronic Disease Nutrition. Dietary Care, 5, 66-74.

Li, Y. and Schellhorn, H.E. (2007). New developments and novel therapeutic perspectives for vitamin $\mathrm{C}$. Journal of Nutrition 137, 2171-2184.
Mangels, A.R., Holden, J.M., Beecher, G.R., Forman, M.R and Lanz, E. (1993). Carotenoids content of fruits and vegetable; an evaluation of analytic data. Journal of American Diet Association, 93, 284-296.

Ogwumike, O.O. (2002). Hemopoietic effect of aqueous extract of the leaf sheath of Sorghum bicolor in albino rats. African Journal of Biomedical Resources, 5, 69-71

Rock, E., Winklhofer-Roob, B.M., Ribalta, J., Scotter, M., Vasson, M.P., Brtko, J., Bigelious Flohe, R.N, Bronner, A. and Azais-Braescoli (2001). Vitamin A, Vitamin $\mathrm{E}$ and Carotenoids status and metabolism during aging, functional and nutritional consequences. Journals of Nutrition and Cardiovascular Diseases, 11, 70-73.

Singleton, V.L., Oruofer, R. and Lamula Raventos, R.M. (1999). Analysis of phenol and other oxidation substrate and antioxidants by means of FolinCiocalteau's reagent. Method of Enzymology, 299, 152-178.

Spínola, V., Mendes, B., Câmara, J.S. and Castilho, P.C. (2013). Effect of Time and Temperature on vitamin C stability in Horticultural extracts. UHPLC-PDA vs iodometric titration as analytical methods. $L W T$ Food Science and Technology, 50(2), 489-495.

Tedesco, I., Russo, M., Russo, P., Iacomino, G., Russo, G.L. and Carraturo, A. (2000). Antioxidant effect of red wine polyphenols on red blood cells. The Journal of Nutritional Biochemistry, 11(2), 114119.

Tenge, C. and Geiger. (2001). Alternative Fermented Beverage - functional drinks. Master Brewers Association of America Technical Quarterly, 38(1), 33-35.

Tom, V., Rodolfo, J.H, James, E.S., Qing-Li, W. (2013). Hibiscus sabdariffa: Phytochemistry, Quality Control, and Health Properties. ACS Symposium Series, 1127(14), 209-230.

WCRF. (2011). World Cancer Research Fund. Expert Report: Food, Nutrition, Physical Activity and the Prevention of Cancer: a Global Perspective. Retrieved February 2011 from WCRF website: http://www.dietandcancerreport.org/? p=ER 2007

Wiwat, W. (2008). Nutrition data and antioxidant capacity of soymilk ice cream. Asian Journal of Food and Agro-industry 1(04):205-212.

Wood, C. and Pitler, M.H. (2000). Comparison of efficacy of ginger with various anti-motions sickness drugs. British Journal of Anaesthesia, 84(3), 367371. 